\title{
Archaeological Testing of Site 41WM443 Williamson County, Texas
}

Wayne C. Young

Follow this and additional works at: https://scholarworks.sfasu.edu/ita

Part of the American Material Culture Commons, Archaeological Anthropology Commons, Environmental Studies Commons, Other American Studies Commons, Other Arts and Humanities Commons, Other History of Art, Architecture, and Archaeology Commons, and the United States History Commons

Tell us how this article helped you.

This Article is brought to you for free and open access by the Center for Regional Heritage Research at SFA ScholarWorks. It has been accepted for inclusion in Index of Texas Archaeology: Open Access Gray Literature from the Lone Star State by an authorized editor of SFA ScholarWorks. For more information, please contact cdsscholarworks@sfasu.edu. 


\section{Archaeological Testing of Site 41WM443 Williamson County, Texas}

\section{Licensing Statement}

This is a work produced for the Texas Department of Transportation (TxDOT) by the report producer. TxDOT and the report producer jointly own all rights, title, and interest in and to all intellectual property developed under TXDOT's contract with the report producer. The report may be cited and brief passages from this publication may be reproduced without permission provided that credit is given to both TxDOT and the report producer. Permission to reprint an entire chapter, section, figures or tables must be obtained in advance from either the Supervisor of the Archeological Studies Branch, Environmental Affairs Division, Texas Department of Transportation, 125 East 11th Street, Austin, Texas, 78701 or from the report producer 
ARCHAEOLOGICAL TESTING OF SITE 41WM443

WILLIAMSON COUNTY, TEXAS

\section{By}

Wayne C. Young

Texas

State Department of Highways and Public Transportation

Highway Design Division

May 1985 


\section{ABSTRACT}

Testing of Site 41WM443 along FM 1431 in Williamson County, Texas, to determine eligibility for inclusion within the National Register of Historic Places and to determine site depth, cultural context, and archaeological significance was undertaken in April 1985. The site is located along a ridge line containing an outcrop of good quality Georgetown flint. Almost all the area within the right-of-way consisted of exposed bedrock ledges. One small incipient burned rock midden was present within the right-of-way. The midden measured 5 meters in diameter, but about half of it had been destroyed by relic hunters. Results of the survey and testing indicate that portions of $\mathbf{4 1 W M} 443$ within the right-of-way contain a prehistoric component of unknown age and that the major activities were concerned with the procurement of flint and lithic reduction. No features, diagnostic artifacts, or organic remains were recovered although the testing procedures removed most of the burned rock midden. Evidence recovered does not support a determination of eligibility for inclusion within the National Register of Historic Places for the portions of the site within the right-of-way. 


\section{INTRODUCTION}

Archaeological Site $41 \mathrm{WM} 443$ was recorded at the Texas Archeological Research Laboratory of the Balcones Research Center, The University of Texas at Austin, in September 1972 by a member of the State Department of Highways and Public Transportation (SDHPT) professional cultural resources staff. Following initial evaluation, further investigation and testing were recommended. During the period of April 10-16, 1985, testing operations were conducted by Wayne C. Young of the SDHPT cultural resources staff, with field support personnel provided by the SDHPT District 14 Burnet residency office.

Testing of Site 41WM443 was perfomed under the Memorandum of Understanding between the SDHPT and the Texas Antiquities Committee. The object of the test was to determine eligibility for inclusion of the site within the National Register of Historic Places and to determine the nature of the deposits and the cultural context of the site.

The highway construction project affecting Site $41 \mathrm{WM} 443$ provides for the construction of a four-lane highway from the Chandler Road overpass on IH 35 to FM 1431 at US 183 in Cedar Park, Texas. This is a new construction project involving a $200 \mathrm{ft}$-wide right-of-way along the 8.76 mile route.

Site $41 \mathrm{WM} 443$ is located about $4500 \mathrm{ft}$. west of the Chandler Road overpass on IH 35 (Fig. 1). The site consists of a lithic procurement area and associated burned rock middens along a ridge line that contains an outcrop of good quality Georgetown or Edwards flint. The site limit was not determined but the site appears to extend for at least a mile along the ridge paralleling the highway. Most of the site consists of exposed limestone bedrock with numerous flint nodules and flakes lying on bedrock or in small catchment basins in the rock. There is a small incipient burned rock midden within the right-of-way, a large burned rock midden 30 meters north of the right-of-way, and two large middens about 100 meters south of the right-of-way. The observed middens are on the eastern slope 
This Page Redacted Per THC Policy 
of the ridge line. Interestingly, there is no current water source along the ridge but there may be springs in the area which were not located during the examination of the site. 


\section{SITE DESCRIPTION}

Site 41 WM443 is located about $4500 \mathrm{ft}$. west of the Chandler Road overpass on IH 35. The site consists of a lithic procurement area extending for at least a mile along a limestone ridge line containing good quality Georgetown flint. Scattered flint nodules, cores, and flakes are common along the exposed bedrock of the ridge line and suggest that a large amount of lithic reduction was performed at the site. There are also a minimum of four burned rock middens associated with the lithic procurement site although only one is located within the right-of-way of 1431.

The midden within the right-of-way is the smallest such feature observed at the site. It appears to have been an incipient burned rock midden and is about 5 meters in diameter with a maximum thickness of $45 \mathbf{c m}$. Testing indicated that it was built in a bedrock depression. Bedrock occurs on all sides of the midden as a series of steps or benches. There is a small amount of topsoil with flint flakes around these steps but the material is thought to have washed into these catchment basins and does not represent intact cultural deposits.

Relic hunters have destroyed roughly half of this burned rock midden since the discovery of the site in 1972. The eastern or lower half of the midden has been looted extensively, leaving only the western 3 meters for testing. 


\section{TESTING OPERATIONS}

Archaeological testing of Site 41WM443 consisted of surface observations and excavations of test units by hand (Fig. 2). The testing operations were concentrated in and around the burned rock midden and this was the only area with any soil deposition. The remainder of the site was exposed bedrock. Three 2 meter squares were dug into the deposits and vertical control was in arbitrary 10 an levels unless bedrock was encountered before that depth. Shovels, picks, and trowels were used to remove the soil and burned rock; and all matrix was passed through 0.25 in. mesh hardware cloth screens. All material recovered was bagged and labeled by test unit and level coordinates and was removed from the site for analysis and temporary storage at the SDHPT Laboratory for Archaeological Studies.

Excavation unit placement was limited by the lack of soil within the rightof-way and by concern with the burned rock midden. Test Units 1 and 3 were dug into the intact portions of the midden while Test Unit 2 was placed along the eastern edge. Test Unit 1 was placed in the northwest quadrant of the midden and excavated to bedrock. This unit contained two large limestone slabs along the south wall which were thought possibly to represent a feature atop solid bedrock.

Test Unit 3 was excavated adjacent to Test Unit 1 to expose a larger area and to see if the rocks represented a feature. The floor of this unit was largely covered with large slabs lying on bedrock. The lack of burning on these slabs and the unpatterned nature suggest that these were natural and did not represent a cultural event.

Test Unit 2 was excavated into a large bedrock catchment basis along the eastern edge of the midden, Bedrock was encountered at less than $10 \mathrm{~cm}$ across this unit, with most of it being less than $5 \mathrm{~cm}$ beneath the present ground surface. 


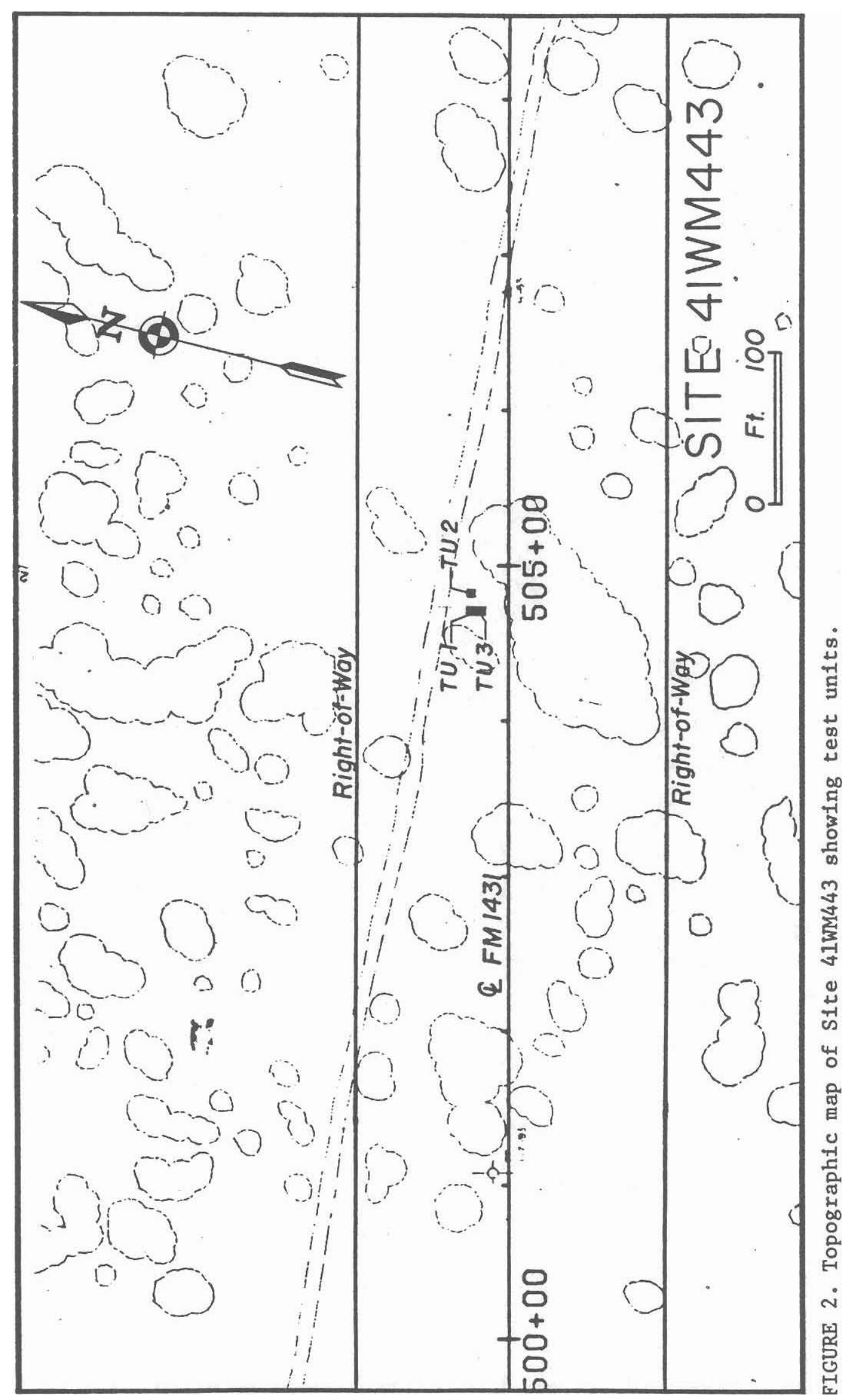




\section{TESTING RESULTS}

Artifact recovery from the testing of 41 WM443 included a quantity of 1 ithic debitage and aborted bifaces but no bone, snails, mussels, features, or temporally diagnostic artifacts. The lithic sample is related to the early stages of lithic reduction, as might be expected with the midden located on a lithic procurement area.

Level 1 of Test Unit 1 contained 1 core, 18 chunks of flint, 100 interior flakes, and 61 cortex flakes. Level 2 contained 1 thin triangular biface, 2 core fragments, 1 side scraper fragment, $19 \mathrm{flint}$ chunks, 153 interior flakes, and 89 cortex flakes.

Test Unit 3, adjacent to Test Unit 1, contained 3 cores, 10 flint chunks, 38 interior flakes, and 42 cortex flakes in Level 1 . Level 2 held 3 cores, 2 biface fragments, 3 scrapers, 36 chunks, 179 interior flakes, and 73 cortex flakes.

Test Unit 2 contained 2 cores, 1 modified flake, 1 side and end scraper, 58 flint chunks, 168 interior flakes, and 114 cortex flakes.

The testing operations also provided a midden profile which is shown in Figure 3. This profile spans most of the burned rock midden and indicates that this cultural feature was constructed in a natural bedrock depression which had a number of large, loose limestone slabs lying on bedrock. These slabs were not removed prior to the midden construction and their lack of burning suggests that they were not used for cultural activities within the burned rock midden. 


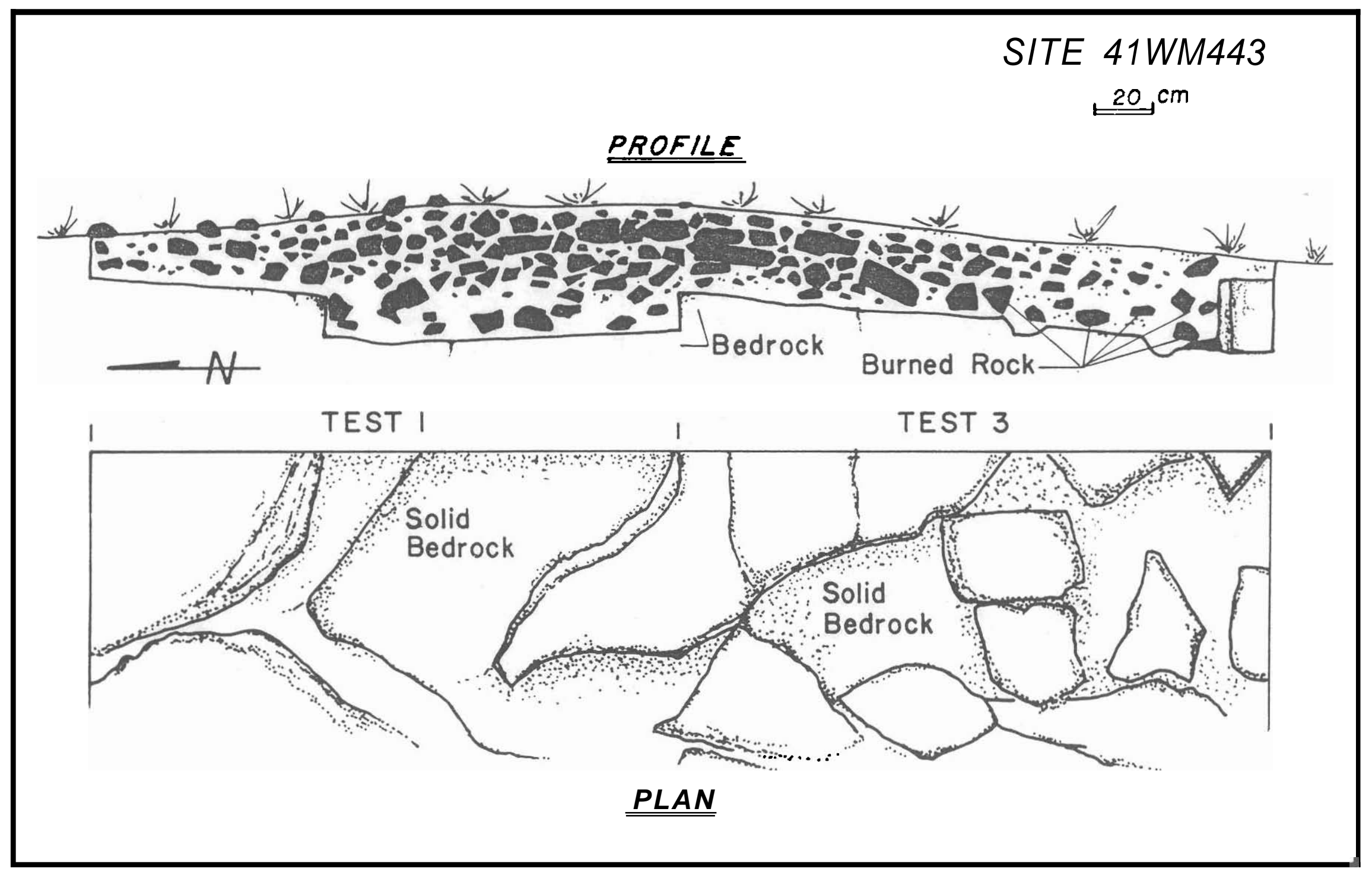

FIGURE 3. Profile of midden and plan view of test units with burned rocks removed. 
Further research is not warranted on the portions of 41 WM443 within the right-of-way for FM 1431. Testing procedures have provided a sample of materials from within the burned rock midden and have largely eliminated all areas with intact cultural deposits. The site is thought to represent primarily a lithic procurement and early reduction center and was used secondarily as a habitation site, most likely over a span of several thousand years. Unfortunately, the temporal parameters are unknown and cannot be controlled. The portions of $41 \mathrm{WM} 443$ within the SDHPT right-of-way do not warrant inclusion within the National Register of Historic Places. Parts of the site outside the right-of-way may meet the criteria for inclusion, but these areas are beyond the jurisdiction of the SDHPT. 